\title{
Ethnic diversity decreases turnout. \\ Comparative evidence from over 650 parliamentary elections around the world
}

\author{
Ferran Martinez i Coma \\ Centre for Governance and Public Policy and Griffith Asia Institute, Griffith University \\ (f.martinezicoma@griffith.edu.au) \\ and \\ Alessandro Nai \\ Department of Government and International Relations, University of Sydney \\ (alessandro.nai@sydney.edu.au)
}

\begin{abstract}
Ethnic diversity has been shown to play a significant role in public goods provision, economic growth and government quality, to mention a few. However, we do not know which is the impact of ethnic diversity on turnout. In this article, we determine which dimensions of ethnic diversity affects turnout. To do so, we have gathered data from over 650 parliamentary elections in 102 democracies covering over a fifty-year period. Our models and seven complementary robustness checks show that elections in countries with more fractionalised, more polarised and more concentrated ethnic groups have a significantly and substantially lower turnout.
\end{abstract}

\section{Keywords}

Ethnic diversity, turnout, elections, comparative analysis

\section{Introduction}

In recent years, studies of turnout at the aggregate level have been prolific. For instance, research has shown that there is a negative relationship between corruption (Stockemer et al., 2011), the size of the political community (Remmer, 2010), the level of economic integration (Steiner, 2010) and turnout. Terrorism can lead to anxiety in the electorate which, in response, increases its attention and consequently increases turnout (Robbins, Hunter and Murray, 2013). Turnout functions in highincome countries are different from low-income countries (Stockemer, 2015). Turnout at legislative elections varies inversely with presidential power (Elgie and Fauvelle-Aymar, 2012). Moreover, turnout determinants in democracies are different from those in non-democracies (Martinez i Coma, 2016). In Sweden, for example, rain does not impact turnout (Persson et al., 2014), but it does in the US (Gomez et al., 2007) and in Spain (Artes, 2014).

Ethnic diversity, however, has not captured the attention it deserves. For example, Blais and Dobrzynska (1998) in their frequently cited study on global coverage include the size of the population, the GNP per capita, its per capita growth, the average life expectancy, the degree of illiteracy and the density of the population. Additional area-specific studies are no exception. In his analysis for 324 Western elections, Franklin (2004) did not include ethnic diversity Studies with other geographic scopes are no different: Kuenzi and Lambright (2007) for Africa, Fornos, Power and 
Garand (2004) for Latin America and Kostadinova (2003) covering East European elections did not incorporate the country's ethnic diversity. Some studies have incorporated ethnic diversity as a control (Fumagalli and Narciso, 2012), but the focus of their analyses was not on such a variable.

Such an absence is striking when considering the role that academic work has given to ethnic diversity. To mention a few, high levels of ethnic diversity negatively affect public goods provision (Habyariamana et al., 2007; Alesina et al., 1999), investment (Mauro, 1995), economic growth (Easterly and Levine, 1997) and the quality of government (La Porta et al., 1999; Alesina and Zhuravskaya, 2011). Lublin (2015) found that in ethnically diverse countries parties proliferate regardless of the electoral system, though in proportional systems, the effect is stronger. Costa and Kahn (2003) affirmed that 'more homogeneous communities foster greater levels of social-capital production'. Their study of 15 different empirical papers led them to state that 'all these studies have the same punch line: heterogeneity reduces civic engagement. In more-diverse communities, people participate less' (2003: 15).

Certainly, Geys (2006) widely cited meta-analysis of 83 articles mentions 27 studies 'that include a variable measuring the presence of 'minority groups' or their share in the total population' (2006: 645), and 10 of these studies consider the effect of population homogeneity. However, the consideration of ethnic diversity as a variable is far from being systematic. More recently, Cancela and Geys (2016) expanded Geys' initial analysis by adding some subnational studies. About 10 per cent of those works do consider ethnic diversity. But, in the same way that turnout varies within the same district at different levels of government, we cannot assume the same impact of ethnic diversity (Morlan, 1984).

In that regard, this work serves a dual purpose. First, along the lines of previous works that have included ethnic diversity, this article focuses on whether it affects turnout. The second purpose and the main contribution of this article is its unpacking of the impact of ethnic diversity on turnout when distinguishing three of the most salient dimensions of ethnicity: the number of groups (fractionalisation), the concentration of ethnic groups and their size (polarisation). Additionally, it does so by including more elections and countries worldwide. Concretely, we have gathered data from over 650 parliamentary elections in 102 countries worldwide covering the 1960-2008 period.

We show that countries that are more fractionalised, more polarised and have more concentrated ethnic groups tend to vote less. These findings have clear implications for both scholarly and policy literature in different ways. For scholars, we demonstrate that when analysing turnout at the aggregate level, ethnic diversity is a variable that must be considered. From a policy perspective, by learning whether and how ethnic diversity affects turnout, organisations can be more efficient in their efforts to strengthen civic participation.

The second section addresses the reasons to consider ethnic diversity in studies on turnout. The third section discusses the link of the three complementary dimensions of ethnic diversity (number, size and concentration of ethnic groups) with turnout. The fourth section details measurement and methodological issues. The fifth section presents the results and the sixth concludes the article.

\section{Ethnic diversity and turnout}

This paper focuses on whether and which dimensions of ethnicity explain turnout in democracies. The first reason to consider ethnic diversity is the evident gap between reality and academic literature. The importance of ethnic diversity in the political realities of contemporary societies is clear: not only have there been ethnic conflicts around the globe but there have also been political parties that use 'ethnicity', broadly defined, as a powerful mobilisation tool (Scarritt and Mozaffar, 1999). 
Second, ethnic diversity plays a role at the individual level. Previous research -especially that which has focused on Africa-has examined the impact of ethnicity on the direction of the vote. At the individual level, broad correspondence has been found between a voter's ethnicity and vote choice. There have been two approaches. On the one hand, theories have considered ethnic vote as an expressive act: 'voting is not act of choice, based on a rational weighing of alternatives, but an expression of allegiance to a group' (Ferree, 2006: 804). On the other hand, theories have presented ethnic voting as an instrumental act. For instance, in their analysis of 22 public opinion polls in 10 African countries, Eifer, Miguel and Posner (2010) found that ethnic identities are strengthened by exposure to political competition and that they are useful in the competition for political power. But vote support is different than ethnicity as a mobilising factor.

Some studies, however, have determined that ethnicity may not be as important as suggested. Instead of relying on the expressive or instrumental explanations, such works proposed that voting depends on economic and policy performance of the governments. For example, Norris and Mattes (2003) found that ethnic cleavages matter but that evaluations of policy performance also play a significant role. Along the same lines, Bratton, Bhavnani and Chen showed that approval of the government's managing economic policy increases the likelihood that respondents will vote for the candidate, even if they are from different ethnic groups (Bratton et al., 2012). Moreover, through a survey experiment in Kenya, Long and Gibson (2012) discovered that when respondents had to choose between a non-co-ethnic candidate who performed well in office and/or one who did not deliver but was from the respondents' same ethnic group, the majority selected the former. Additionally, when conducting an experiment in Uganda, Conroy-Krutz (2013) found that ethnicity had a substantial impact on individuals' decisions when limited information was available; however, the impact of ethnicity declined as the costs of information decreased.

Third, ignoring the impact of ethnicity means assuming that other 'more genuine' variables (e.g. population or electoral system) are the basis for political mobilisation. Without denying the importance of these elements, the exclusion of 'ethnicity' from the analysis is, at best, artificial. In many countries, ethnic affiliations 'provide a sense of security in a divided society, as well as a source of trust, certainty, reciprocal help, and protection against neglect of one's interests by strangers' (Horowitz, 1993: 32). Ethnicity could matter for turnout and for politics as the non-ethnic Estonians, who accounted for almost 40 per cent of the population, could attest when they were disfranchised by the citizenship law in 1992 (Järve and Poleschuk, 2013).

Finally, from a policy perspective, it is also worth knowing the impact of ethnic diversity on turnout. At the end of any given year, domestic and international organisations invest in numerous resources in get out the vote campaigns in different countries. Knowing whether ethnic diversity is a factor that matters may reduce practitioners' uncertainty.

\section{How does ethnic diversity impact turnout? Competing hypotheses}

Ethnic diversity is a multidimensional concept. A priori, many of those dimensions may impact turnout at the aggregate level. We focus on three of the most salient dimensions that have been analysed: the number of groups (fractionalisation), their degree of concentration and their size (polarisation). For analytical purposes, we present each dimension individually. In the empirical section, we will also consider how the three dimensions interact simultaneously.

\subsection{Number of groups (fractionalisation)}


The first dimension of ethnic diversity is the number of groups. Existing literature might point to either a positive or a negative effect on turnout. First, as fractionalisation increases, evidence has pointed to a negative correlation of ethnic diversity with, for example, trust (Glaeser et al., 2000), group membership (La Ferrara, 2002), government performance and growth (La Porta et al., 1999; Alesina et al., 2003), tax morale (Lago-Peñas and Lago-Peñas, 2010), efficient judiciaries (La Porta et al., 1999) public good expenditures (Alesina et al., 1999) or the size of welfare states (Alesina et al., 2001).

According to Alesina and La Ferrara (2000), more homogeneous communities show a higher level of interactions (which, in their research, consequently leads to higher social capital). They discovered that participation in social activities in the United States is lower in (racially) fragmented communities (2000) and that trust is higher in homogeneous communities (2000). ${ }^{i}$ This is due to two interrelated arguments. First, social interactions, such as turnout, should be higher in more compact ethnic countries 'because of shared interests, socialisation to the same cultural norms, and greater empathy toward individuals who remind them of themselves' (Costa and Kahn, 2003: 104). As long as preferences correlate with ethnicity, the assumption is that people will prefer to self-segregate, which translates into joining groups that are along their similar ethnic lines. Second, in order to build social capital, personal interactions are vital. Such interactions are possible only if everyone goes to the meeting groups and/or the distances can be travelled. In consideration of transportation costs, a minority group may not be viable to form in a concrete area. The only options are to either join a larger group or refrain from participating. Consequently, we would only observe increases in overall participation if the minority group increases enough to become its own independent group. Alesina and La Ferrara (2000)'s results concerning U.S. cities showed that racial and ethnic heterogeneity reduces the propensity to participate in social activities. Overall, and expanding on the previous reasoning and findings, which are also echoed in Europe (Grönlund and Setälä, 2007), we should expect that in more diverse societies, turnout should be lower.

However, there are two arguments indicating that the number of groups should lead to increased turnout. First, according to Alesina and La Ferrara's (2000) model, turnout may increase in heterogenic context if the minority groups form their own group. Similarly, Anduiza (1999) stated that mobilisation and, consequently, turnout increase since social heterogeneity fosters party-voter linkages. The empirical evidence, however, is not clear.

In more diverse heterogeneous societies, we could observe higher turnout because of their mere societal composition. As Oliver argued (1999: 91), 'Local politics should be more contentious (and participation highest) in economically diverse cities as these places have more groups pursuing contradictory goals. Conversely, a greater consensus over local policy in economically homogeneous cities should limit competition, citizen interest, and participation'. The underlying assumption is that more heterogeneous societies have more distinct preferences to accommodate than more homogeneous societies. This assumes that different ethnic groups have varied (and maybe contradictory) interests. In order to represent the different preferences, turnout is the first reasonable strategy to achieve it.

For example, in Indonesia, ethnic fractionalisation is extremely high (above .7). The accommodation of the preferences of such groups is more difficult than it is in El Salvador, a low ethnically fractionalised society (below 0.2 ). In Indonesia, turnout is extremely important for all their groups to have their interests represented-indeed, turnout was about 77 per cent in 2004. In El Salvador, where citizens can expect that their preferences are not extremely different from their fellow countrypersons, turnout did not reach 40 per cent in 1997.

The second reason to expect higher turnout in more ethnically diverse societies is derived employing a rational choice perspective. It could be logical to expect that the higher the number of groups, the 
more parties should mobilise among ethnic lines and the higher the voter turnout. If competition existed among ethnic or religious groups, parties and candidates would have to maximise their group's standing and thus turnout for a candidate or party associated with their ethnicity. This is precisely the case in Ghana, where some parties are associated with specific ethnic groups. In particular, the New Patriotic Party 'is associated with the Akan, Ghana's largest ethnolinguistic group with 45 per cent of the country's population, and particularly with the Ashanti subgroup', while the National Democratic Congress (NDC) is linked to the 'Ewe ethnic group of its founder, former President Jerry Rawlings' (Ichino and Nathan, 2013: 348). In such settings, it is reasonable to expect candidates' actions to mobilise the electorate to involve playing the ethnic card (Eifert, Miguel and Posner, 2010). The assumption is that ethnic groups have different interests and candidates exploit these interests. At the extreme, this can be dangerous. For example, in Kenya, 'once multiple parties were allowed to compete for office in 1992, political coalitions formed along ethnic lines, and in both the Rift Valley and Cast provinces individuals were attacked for both their ethnic identity and partisan affiliation' (Kasara, 2013: 925). Overall, based on those arguments, we should expect that in more diverse societies, turnout should be higher.

\subsection{Concentration of the groups}

Group concentration conditions, the context in which its members interact, factor into their ability to mobilise for turnout. It determines groups' opportunities for mobilisation.

Group concentration has been present in the study of turnout at the local level, leading to competing hypotheses. According to theories of acculturation, if a concrete disadvantaged ethnic group is concentrated, they are less likely to participate (Lien, 1994). Along the same lines, Massey and Denton (1989) stated that the segregation of urban blacks in the US during the 1970s led them to withdraw from society, which consequently precipitated a lower lever of political participation. Huckfeldt (1986) also argued that people living in incongruous and diverse social environments were less likely to participate. In Spain, this situation is replicated with the gypsies, as Gomez Fortes and Trujillo Carmona (2011) found there is high relation between abstention levels and gipsy concentration.

Social capital theory predicts the opposite: there will be higher levels of bonding social capital in areas where a racial, religious or ethnic group is more spatially correlated. Consequently, turnout may be increased through political mobilisation within those communities (Fieldhouse and Cutts, 2008). As Schlichting, Tuckel and Maisel suggested, 'The demographic concentration of minority members within a compact spatial area would facilitate the growth of political organisations and the ability to mobilise rank and file members', and 'an ethnic community is more likely to emerge among minority members who live in areas populated mainly or exclusively by minority residents' (1998: 220). Moreover, Gurr and Scarritt (1989) stated that 'political mobilization [...] is likely to be easier among concentrated rather than dispersed groups' (391).

\subsection{The size of the groups (polarisation)}

The final dimension of ethnic diversity that may impact turnout is the size of the groups (polarisation). Horowitz (1985) observed that in diverse and homogeneous societies, ethnic conflict should be a rare event. However, in societies with a large minority group and a small majority group, conflict should be higher. As Huber stated (2012), such a perspective 'is based on the premise that group based (or party-based) governance problems are greatest when there are two equal-sized groups' (987). Posner agreed when commenting that the 'political salience of a cultural cleavage will depend on the sizes of the groups that it defines relative to the size of the arena in which political competition is taking place' (2004: 529) and relied on a natural experiment between Chewas and Tumbukas in Zambia and Malawi. 
Translating this to turnout, at the extremes of diversity, size should not be a factor when 1) there is one sizable, dominant group and one small minority group; 2 ) there are many small minority groups and no dominant groups. The reasoning is that in situation 1, the dominant group-assuming different preferences-will always control the results. In situation 2, no group is able to impose its will and, consequently, turnout should not be affected. However, if there is a small majority and a large minority, we should expect higher turnout, given that there is a lot at stake.

\section{Data, variables and methods}

\subsection{Elections and countries}

Our database covers most of the parliamentary or lower House elections ii held in democracies after 1960 for national political offices in independent nation states ${ }^{\text {iii }}$ and where the franchise was universal. ${ }^{\text {iv }}$ We follow Cheibub, Gandhi and Vreeland's (2010) definition and conceptualisation of democracy ${ }^{v}$, while in the robustness checks we rely on alternative measures. Our database is composed of 659 parliamentary elections in 102 countries covering the 1960-2008 period. $^{\text {vi }}$

\subsection{Dependent variable: Turnout}

The definition of turnout varies. The majority of studies agreed on the number of valid votes cast being the numerator. The differences are in the denominator, since voting age population, number of eligible voters, number of registered or the size of the electorate could be considered (Geys, 2006). We define turnout as the number of votes cast divided by the voting age population for three reasons. First, it is the most common in the literature (Geys, 2006). ${ }^{\text {vii }}$ Second, by considering the voting age population (VAP), which includes all citizens above the legal voting age, we avoid the use of registration figures. Third, those figures can 'provide a clearer picture of participation as they signal a problem with the voters' register or registration system' (IDEA, 2002: 10). viii The mean turnout in our database is 68.4 per cent, covering countries such as Jamaica, Guatemala, Mali, Uruguay and Malta.

Two main different sources have been used to gather data on turnout in elections: the Institute for Democracy and the Electoral Assistance (IDEA) website on voter turnout and the works of Dieter Nohlen and associates $(1999,2001,2005)$. The rationale for using these two sources is threefold. First, these are the most used sources. Second, given the administrative structure in some countries, it is better to have multiple sources. The correlation between them and the over 1,300 elections that overlap is over $R=0.95(p<.001) .{ }^{\text {ix }}$ Third, the period covered by the two sources is slightly different: Nohlen and colleagues' coverage ranges from the years of independence (and earlier) and stops in 1999. When there is no overlap between the two primary sources, we rely on Adam Carr's Inter Parliamentary Union (IPU) and the African Elections Database. When there were evident errors, we amended them. ${ }^{x}$

\subsection{Independent variables: three dimensions of ethnic diversity}

In order to measure ethnic diversity, we rely on structural measures, 'those identities that are considered commonsensically real by a population', regardless of whether or not individuals identify with them (Chandra 2009: 309). ${ }^{\text {xi }}$

\subsubsection{Operationalisation of the number of groups (fractionalisation)}

The first study to use a structural approach to ethnic fractionalisation was the Atlas Narodov Mira (1964). The authors identified the proportions of ethnic groups along with an approximation with 
their respective population size. The Herfindahl concentration index, one of the most common measures accounting for ethnic diversity, directly stems from their work. The index is defined as the probability that two individuals selected at random from a country will be from different ethnic, linguistic or religious groups. The formula is:

$$
\mathrm{FRACT}_{j}=1-\sum_{i=1}^{n} \mathrm{~S}_{i j}{ }^{2}
$$

where $s_{i j}$ is the proportion of group $i(i=1 \ldots N)$ in country $j$. The higher the resulting score, the higher fractionalisation will be.

Easterly and Levine (1997) used such a measure to explain growth in 129 countries for three decades (1960-1980). Alesina et al. expanded the coverage to 190 states and used 'the same formula, applied to different underlying data' (2003: 159). Their main source was the Encyclopedia Britannica. Roeder (2003) incorporated the same sources for his measures for 1961 and 1985. Fearon used the CIA's World Factbook, Encyclopedia Britannica and 'the relevant Library of Congress Country Study' (2003: 202) and identified groups that had at least 1 per cent of the country population in the 1990s. Montalvo and Reynal-Querol (2005a, 2005b) relied on the World Christian Encyclopedia as their main source as well as several others to complement their classification and also to follow Vanhanen (1999) 'in order to identify the relevant level of disaggregation' (2005a: 300).

These authors use different sources identifying different ethnic groups. For example, Roeder (2003) classified 631 different ethnic groups in 130 countries, while Fearon (2003) recognised 822 ethnic and ethnoreligious groups in 160 countries. In this article, we rely on Alesina et al.'s (2003) conceptualisation because it has the widest country coverage and is one of the most cited. In the robustness checks, we use other conceptualisations. Figure 1 presents the world distribution of Alesina et al.'s (2003) fractionalisation measure. Although it is a continuous variable, we have grouped it in four categories to better show its variance around the globe. Africa is the continent with the average highest degree of ethnic fractionalisation, followed by the United States and Asia.

[Figure 1 about here]

Table 1 presents the correlations of the competing measures of fractionalisation for all elections in our dataset. The table clearly highlights that all measures are highly correlated, which most likely indicates that they capture the same concept.

[Table 1 about here]

\subsubsection{Operationalisation of group concentration}

Group concentration is operationalised following a structural approach. Structural concentration can be assessed either by focusing on territorial concentration (number of areas-and their size--in which any given enthnopolitical group settles) or by looking at how far apart the concentrated same group of individuals (population dispersion) are. The former focuses on territory and the latter focuses on individuals. Weidmann (2009), using geographic information systems (GIS) data, estimated those two measures of structural concentration for 72 countries in Europe, Asia and North Africa.

The measure for territorial concentration takes this form: 


$$
S=\sum_{i=1}^{n} a\left(c_{i}\right)^{2}
$$

where $a\left(c_{i}\right)$ is the area of a cluster $c_{i} . S$ takes a value between 0 and 1 , with 0 signalling very scattered groups and 1 signalling very territorially concentrated groups.

The measure for population dispersion includes the distances between clusters. ${ }^{\text {xil }}$ Weidmann offered the degree of dispersion for each individual group in each country. In order to create a comparable measure across countries, we have created the average of each value for each country. This measure is not perfect, since there may be countries in which different ethnic groups show different concentration patterns and consequently would not have all the desired informational power. However, it allows us to have a first indicator on the level of group concentration at the country level. Territorial and population measures of concentration correlate negatively to a very high degree $(R=-.86)^{x i i i}$, signalling that they are capturing two sides of the same concept.

\subsubsection{Operationalisation of the size of the group (polarisation)}

Finally, we focus on the size of the group, also known as polarisation. Such a perspective 'is based on the premise that group based (or party-based) governance problems are greatest when there are two equal-sized groups' (Huber, 2012: 987). Polarisation builds on Horowitz's (1985) observation: in extremely diverse and extremely homogeneous societies, ethnic conflict should be a rare event. However, in societies with a large minority group and a small majority group, conflict should be higher. Reynal-Querol (2002) and Reynal-Querol and Montalvo (2005a, 2005b) developed a measure of ethnic polarisation based on this premise. Their measure, known as the ethnic polarisation (RQ) index, will be maximised the more equal the groups are. It is computed through:

$$
R Q_{i}=1-\sum_{i=1}^{n}\left(\frac{1 / 2-\pi_{i}}{1 / 2}\right)^{2} \pi_{i}
$$

where $\pi_{i}$ is the size of group $i(i=1 \ldots N)$. The higher the index, the more polarised the society is. The value of the index ranges from 0 to 1 and takes values 0.1 for countries such as Portugal but takes values above .8 in Belgium. ${ }^{\text {xiv }}$ Hence, the operationalisation of this variable is the most suitable to test the hypothesis.

In summary, our article tests the effects on turnout in elections of three different dimensions of ethnic diversity. Table 2 presents an overview of those dimensions.

[Table 2 about here]

\subsection{Controls}

There is no consensus in the literature about which independent variables must be included in the models studying turnout at the aggregate level (Martinez i Coma, 2016). A comparison of the works of Blais and Dobrzynska (1998) on global coverage and Geys (2006) work on meta-analysis shows that their agreement is on the inclusion of institutional factors such as the electoral system or whether elections are concurrent. Unsurprisingly, in a recent review that covered the 2004-2013 period, Stockemer identified 135 studies and over 100 different variables, which led him to affirm that 'no variable is omnipresent' (2016: 15). On societal and political factors, there are more differences than agreements. In that regard, the variables that we include are those that are 'common' in the most widely cited studies. 
In regard to the societal variables, we control for the logarithm of the gross domestic product per capita in US dollars (Gleditsch, 2002), the logarithm of a country's population (Gleditsch, 2002) and the logarithm of the percentage of an urban population (Blais, 2006) from the World Bank. All the data were obtained from the Quality of Government Dataset.

We include four usual institutional (Geys, 2006) variables: whether the elections were concurrent, whether the vote was compulsory, the electoral system (a dummy for proportional systems) and the logged effective number of parties. The first two variables were obtained from the IDEA turnout dataset. For the electoral system, we relied on Nohlen et al.'s work as well as on the IPU. The effective number of parties comes from Bormann and Golder (2013).

We include three political variables. The competitiveness of the contest is normally measured as the gap in vote shares between the first party and the second party. The argument is that more competitive elections should have higher turnout (Blais and Dobrzynska, 1998). We also control for the number of national elections that such a country has held since 1945 and include a dummy variable accounting for those elections held before 1991, signalling the end of the Cold War. Table 3 presents a summary of all the variables in our models (including controls and robustness checks).

[Table 3 about here]

\subsection{Estimation}

Time-serial dependencies and correlated error terms within panels are two common challenges when analysing panel data. To correct for this, we use generalised least square regression models with panel corrected standard errors that are further corrected for panel-specific AR1 autocorrelation and heteroskedasticity. Such models retain a cross-country effect, while taking into account the effect of time-serial dependencies. Alternative models, based on multilevel estimations where elections are nested into countries, are run as robustness checks.

Franklin (2004) suggested the incorporation of a lagged dependent variable (turnout in the previous election) if theoretically valid, but here it is not clear. While past turnout can be a determinant of current turnout, a lagged dependent variable soaks up the explaining powers of static institutional variables, thus producing an incomplete picture and inflating the amount of variation explained (Achen, 2001). The main models exclude lagged turnout, but we include it as a robustness check (see section 5.1).

\section{Results}

Based on the previous discussion, we estimate turnout in parliamentary elections worldwide as a function of three a priori relevant dimensions of ethnic diversity: fractionalisation, concentration and polarisation. All coefficients are standardised to allow a straightforward vis a vis comparison of the impact of the variables.

Table 4 presents six models. The first is a 'base' model and does not include any ethnic diversity variables. Model M2 captures the effects on turnout of the ethnic fragmentation dimension using Alesina et al.'s (2003) measure. Models M3 and M4 capture the effects on turnout of the ethnic concentration dimension relying on Weidmann's (2009) measure of territorial concentration. Model M5 captures the effect of ethnic polarisation while M6 presents a triple interaction with all the dimensions at play. ${ }^{\mathrm{xv}}$

[Table 4 about here] 
From the base model (M1), we verify that turnout is higher in elections with compulsory voting and in PR systems, in line with established findings (e.g. Hirczy, 1994; Franklin, 1999; Blais and Dobrzynska, 1998; Cancela and Geys, 2016). Turnout is lower in countries with a larger population, in less competitive elections and when they were held after 1991. Across the models, there is no evidence on the impact of the urban rate and the number of elections.

Overall, ethnic diversity impacts turnout negatively: more diverse countries tend to vote less. Results show that an increased diversity measured through structural ethnic fragmentation has a negative effect on turnout (M2). This result supports Putnam's (2007) argument that more homogeneous communities experience higher levels of social interactions. Furthermore, this effect is virtually identical regardless of the specific measure of structural ethnic fragmentation used in the analysis (see Table B1 in Appendix B).

Models M3 and M4 test the effects of group concentration. The higher the (average) concentration of different ethnic groups, the lower the turnout. This effect holds across the models and would provide support for the theories of acculturation versus social capital theory. The direct effect of territorial concentration is significantly negative (M3). The effect of group dispersion is significantly positive (M4), which is not surprising given that both dimensions are strongly and negatively correlated.

Model M5 highlights that the higher the ethnic polarisation, the lower the turnout, also controlling for religious polarisation. Such results are at odds with the proposed hypothesis that turnout should be higher in societies with small majorities and large minorities compared to other group size distributions.

As can be seen, all the dimensions of ethnic diversity are significant and point in the same direction: societies that are more fractionalised, more concentrated and more polarised tend to vote less. The three dimensions, however, exist in relation to each other and it would be unusual to suggest that any one of them exists on its own. This is why in $\mathrm{M} 6$ we present an interaction of the three dimensions at play. The non-significant coefficient should be cautiously interpreted as there is a considerable reduction of the number of elections and countries-now only covering 23 countries in Europe and Asia.

Given that the coefficients are standardised, they can be compared in terms of their impact on the dependent variable. As it can be seen across the models, the impact of the ethnicity dimensions is not to be ignored. Specifically, the fractionalisation and the polarisation dimensions ( $M 2$ and M5, respectively) signal their importance with coefficients of the same size, if not higher, compared to the usual controls. Concretely, in M2, ethnic fragmentation is the most relevant independent variable, compared to compulsory voting, the dummies accounting for the electoral system and the level of competitiveness. Similarly, in M5, ethnic polarisation plays a dominant role compared to the rest of the variables, although it is less marked than in $M 2$.

\subsection{Robustness checks}

We have run seven robustness checks. (The results are presented in Appendix B.) The first control considers the impact of different structural measures of ethnic fractionalisation on turnout. Although competing measures exist, they yield similar results (Table B1). Except for the measure of ethnic fractionalisation proposed in the Atlas, all four alternative measures point to virtually identical effects as in the main analyses: higher structural ethnic fragmentation leads to lower turnout.

The second control is the impact of the previous turnout. If the results hold even in terms of controlling for turnout in previous elections, that will be quite definitive evidence of the impact of 
such variables. Table B2 in Appendix B shows that, although previous turnout is a strong predictor of actual turnout (also indicated by the substantial bump upwards of the explained variance for all models), it does not alter the effect of ethnic diversity, which is a good indicator of the robustness of the results. All the coefficients follow the same pattern as in Table 4.

The third robustness check selects countries according to a different definition of democracy: instead of using Cheibub, Gandhi and Vreeland's (2010) definition of democracy, we rely on Polity IV, defining those regimes that score 6 or higher as democracy. There are slight variations in the number of countries included as well as the time coverage of the analysis, but the overall results reported in Table B3 are consistent with the findings in Table $4 .{ }^{\text {xi }}$

We also ran the same models including presidential elections. The logic is that although parliamentary contests show different political dynamics and turnout patterns from presidential contests (Stockemer and Calca, 2012), if ethnic diversity is a relevant factor organising the political competition of any country, it will do so regardless of the competition at stake. Our analyses (Table B4) show identical results, regardless of the type of election.

The fifth robustness check (Table B5) introduces a different definition of the dependent variable. We use the same numerator, i.e. the number of valid votes, but instead of using the voting age population as the denominator, we rely on the registered voters (see Stockemer (2016) for a recent discussion on such differences). The model replicates Table 4, and results do not change.

We have also included corruption (Table B6) as the final robustness check. Stockemer et al. (2011) found that as corruption increases, turnout lowers. We rely on the Varieties of Democracy (V-Dem) indicator. According to V-Dem, 'The corruption index includes measures of six distinct types of corruption that cover both different areas and levels of the polity realm, distinguishing between executive, legislative and judicial corruption. Within the executive realm, the measures also distinguish between corruption mostly pertaining to bribery and corruption due to embezzlement' (2016: 66). Such an indicator ${ }^{\text {xvii }}$ runs from less corrupt to more corrupt. Hence, we should expect a negative coefficient (more corrupt countries, lower turnout), which is what we observe. The results are very similar to those in Table 4.

As the seventh robustness check, we have included a measure for inequality. Relying on individual and country data (2008 and 2010 with US state data), Solt tested the Schattschneider hypothesis, namely that high levels of economic inequality were the cause of high abstention and important differences between the participation rates of poorer and richer citizens. Relying on Milanovic's (2014) calculation on Gini's coefficients, i.e. that higher levels indicate more inequality, we include them in Table B7. Inequality negatively affects turnout, as expected, and the main variables of interest remain significant, although the number of cases drops, which confirms the robustness of the findings. ${ }^{\text {xviii }}$

Finally, it is worth mentioning the weight of the different ethnicity diversity dimensions along all the robustness checks. Overall, in almost every model, the variables of interest are highly relevant. Some dimensions-especially ethnic fragmentation-are just as important, if not more so, than traditional variables, such as compulsory voting, the electoral system, competitiveness and population. In short, the impact of the ethnicity dimensions on turnout is not to be ignored.

\section{Conclusion}


This paper finds that ethnic diversity negatively affects turnout. Overall, our results indicate that societies that are more fractionalised (have a higher number of groups), more polarised (the size of the groups are more even) and have more concentrated ethnic groups tend to vote less. The impact of such ethnic variables is evident and should not be underestimated. We also have shown the relevance of the ethnicity dimensions when compared with the usual control variables. Furthermore, we have run seven robustness checks: different measures of the fractionalisation variable; including the previous turnout rate as an independent variable; an alternative definition of democracy; including presidential elections in the model; changing the denominator of the dependent variable, corruption and inequality with highly similar results.

Academically, the results are important because ethnic diversity has typically been an underplayed variable in the aggregate studies of turnout. We have analysed several diversity dimensions, and the results have shown that it is a highly significant variable and that its importance should not be underestimated. In that regard, it should be considered as a relevant factor, as some recent works have found for corruption (Stockemer et al., 2011) and electoral integrity (Martinez i Coma and Trinh, 2017).

Moreover, ethnicity is a contextual given factor that politicians may decide to strategically apply. For practitioners, the country's level of ethnic diversity is a key variable to consider when promoting turnout campaign. Everything else constant, more diverse countries-measured by fragmentation, polarization or concentration levels-have a lower turnout.

This paper's focus is on whether there is a relationship between ethnic diversity and turnout. Future research should address not only the concrete mechanisms by which this relationship operates but also the role of 'constructivist' measures. Finally, expanding measures on concentration as well as increasing their time sensitiveness will be welcomed in forthcoming endeavours.

\section{References}

Achen, C. 2001. Why Lagged Dependent Variables Can Suppress the Explanatory Power of Other Independent Variables Paper prepared for the Annual Meeting of the Political Methodology Section of the American Political Science Association. http://www.princeton.edu/csdp/events/Achen121201/achen.pdf

Alesina, A. Baquir, R. and Easterly, W. 1999. Public Goods and Ethnic Divisions. Quarterly Journal of Economics 114:243-284.

Alesina, A. Devlesschauwer, A. Easterly, W. Kurlat, S. and Wacziarg, R. 2003. Fractionalisation. Journal of Economic Growth 8:155-194.

Alesina, A. Glaeser, E. and Sacerdote, B. 2001. Why Doesn't the United States Have a European-Style Welfare State. Brookings Papers on Economic Activity 2001, 187-254.

Alesina, A. and La Ferrara, E. 2000. Participation in Heterogeneous Communities. Quarterly Journal of Economics 115 (3): 847-904.

Alesina, A. and Zhuravskaya, E. 2011. Segregation and the Quality of Government in a Cross-Section of Countries. American Economic Review 101 (5): 1872-1911.

Anduiza, E. 1999. ¿'Individuos o sistemas? Las razones de la abstención en Europa Occidental. Madrid: Centro de Investigaciones Sociológicas.

Artes, J. 2014. The Rain in Spain: Turnout and Partisan Voting in Spanish Elections, European Journal of Political Economy: 34, 126-141.

Atlas Narodov Mira.1964. Moscow: Miklukho-Maklai Ethnological Institute at the Department of Geodesy and Cartography of the State Geological Committee of the Soviet Union 
Blais, A. 2006. What Affects Voter Turnout? Annual Review of Political Science, 9: 111-25.

Blais, A., and Dobrzynska, A. 1998. Turnout in electoral democracies. European Journal of Political Research 33 : 239-261.

Bormann, N. and Golder, M. 2013. Democratic electoral systems around the world, 1946-2011, Electoral Studies, 32(2): 360-369.

Bratton, M., Bhavnani, R., Chen, T. 2012. Voting intentions in Africa: Ethnic, economic or partisan? Commonwealth and Comparative Politics 50(1): 27-52.

Cancela, J. and Geys, B. 2016. Explaining voter turnout: A meta-analysis of national and subnational elections. Electoral Studies, 42:264-275.

Chandra, K. 2009. A Constructivist Dataset on Ethnicity and Institutions (CDEI) in Identity as a Variable Rawi Abdelal, Yoshiko Herrera, lan Johnston and Rose McDermott (eds) Cambridge University Press. New York.

Cheibub, J. A. , Gandhi, J., and Vreeland, J. R. 2010. Democracy and dictatorship revisited, Public Choice, 143 (12): 67-101.

Conroy-Krutz, J. 2013. Information and Ethnic Politics in Africa, British Journal of Political Science, 42(02): 345373.

Coppedge, Michael, John Gerring, Staffan I. Lindberg, Svend-Erik Skaaning, Jan Teorell, with David Altman, Michael Bernhard, M. Steven Fish, Adam Glynn, Allen Hicken, Carl Henrik Knutsen, Kelly McMann, Pamela Paxton, Daniel Pemstein, Jeffrey Staton, Brigitte Zimmerman, Rachel Sigman, Frida Andersson, Valeriya Mechkova, and Farhad Miri. 2016. "V-Dem Codebook v6." Varieties of Democracy (VDem) Project.

Costa, D. L. and Kahn, M.E. 2003. Civic Engagement and Community Heterogeneity: An Economist's Perspective. Perspectives on Politics 1:103-111.

Easterly, W. and Levine, R. 1997. Africa's Growth Tragedy: Policies and Ethnic Divisions. Quarterly Journal of Economics 112(4): 203-250.

Eifert, B., Miguel, E. and Posner, D. N. 2010. Political Competition and Ethnic Identification in Africa. American Journal of Political Science, 54: 494-510.

Elgie, R., and Fauvelle-Aymar, C. 2012. Turnout Under Semipresidentialism, Comparative Political Studies, 42(10): 1317-1338.

Encyclopedia Britannica. 2016. http://global.britannica.com/place/Madagascar/Ethnic-groups Retrieved $18^{\text {th }}$ May, 2016.

Fearon, J. D. 2003. Ethnic Structure and Cultural Diversity by Country. Journal of Economic Growth 8:195-222.

Ferree, K. 2006. Explaining South Africa's Racial Census. Journal of Politics 68(4): 803-15.

Fieldhouse, E., and Cutts, D. 2008. Diversity, density and turnout: The effect of neighbourhood ethno-religious composition on voter turnout in Britain. Political Geography, 27: 530-548.

Fornos, C., Power, T. J., and Garand, J. C. 2004. Explaining Voter Turnout in Latin America, 1980 to 2000, Comparative Political Studies 37(8): 909-940.

Franklin, M. N. 1999. Electoral Engineering and Cross-national Turnout differences: What Role for Compulsory Voting?. British Journal of Political Science, 29(1): 205-216.

Franklin, M. 2004. Voter Turnout and the Dynamics of Electoral Competition in Established Democracies Since 1945. Cambridge University Press.

Fumagalli, E. and Narciso, G. 2012. Political Institutions, Voter Turnout, and Policy Outcomes, European Journal of Political Economy, 28: 162-173.

Geys, B. .2006. Explaining Voter Turnout: A Review of Aggregate-Level Research. Electoral Studies 25: 637-663.

Glaeser, E. L. Laibson, D.I. Scheinkman, J.A. and Soutter, C.L. 2000. Measuring Trust. Quarterly Journal of Economics 115 (3): 811-846.

Gleditsch, K. S. 2002. Expanded Trade and GDP Data. Journal of Conflict Resolution, 46: 712-724. 
Gomez Fortes, B. and Trujillo Carmona, M. 2011. "Los excluidos tambien pueden votar: abstencion y exclusion social en Espana" Fundacion Alternativas, Documento de trabajo, 169.

Gomez, B. T., Hansford, T. G., and Krause, G. A. 2007. The Republicans Should Pray for Rain: Weather, Turnout, and Voting in U.S. Presidential Elections, The Journal of Politics 69(3):649-663.

Grönlund, K. and Setälä, M. 2007. Political Trust, Satisfaction and Voter Turnout, Comparative European Politics 5:400-422.

Gurr, T. R. and Scarritt, J 1989. Minorities at Risk: A Global Survey. Human Rights Quarterly 11(3):375-405.

Habyariamana, J., Humphreys M., Posner, D.N. and Weinstein, J.M. 2007. Why Does Ethnic Diversity Undermine Public Goods Provision? American Political Science Review 4:709-725.

Hirczy, W. 1994. The impact of mandatory voting laws on turnout: A quasi-experimental approach. Electoral Studies, 13(1): 64-76.

Horowitz, Donald L. 1985. Ethnic Groups in Conflict. Berkeley: University of California Press.

Horowitz, Donald L.1993. Democracy in Divided Societies Journal of Democracy 4(4):18-38.

Huber, J. D. 2012. Measuring Ethnic Voting: Do Proportional Electoral Laws Politicize Ethnicity? American Journal of Political Science 56(4):986-1001.

Huckfeldt, R. 1986. Politics in Context: Assimilation and Conflict in Urban Neighborhoods. New York: Agathon Press.

Ichino, N., and Nathan, N. L. 2013 Crossing the Line: Local Ethnic Geography and Voting in Ghana. American Political Science Review 107(2): 344-361.

International Institute for Democracy and Electoral Assistance (International IDEA) 2002. Voter Turnout since 1945: A Global Report. Rafael Lopez-Pintor and Maria Gratschew, eds.

Jarve, P. Poleschuk, V. 2013. EUDO CITIZENSHIP OBSERVATORY COUNTRY REPORT: ESTONIA http://eudocitizenship.eu/docs/CountryReports/Estonia.pdf

Kasara, K.2013. Separate and Suspicious: Local Social and Political Context and Ethnic Tolerance in Kenya. The Journal of Politics 75(4): 921-936

Kostadinova, T. 2003. Voter turnout dynamics in post-Communist Europe. European Journal of Political Research 42(6): 741-759.

Kuenzi, M., and Lambright, G. M. 2007. Voter Turnout in Africa's Multiparty Regimes. Comparative Political Studies, 40(6): 665-690.

La Ferrara, E. 2002. Inequality and Group Participation: Theory and Evidence form Rural Tanzania. Journal of Public Economics 85 (2): 235-273.

Lago-Peñas, I. and Lago-Peñas, S. 2010. The Determinants of Tax Morale in Comparative Perspective: Evidence from European Countries. European Journal of Political Economy 26: 441-453.

La Porta, R. Lopez-de-Silanes, F. Shleifer, A. and Vishny, R. 1999. The Quality of Government. Journal of Law, Economics and Organization 15 (1): 222-279.

Lien, P.-T. 1994. Ethnicity and political participation: a comparison between Asian and Mexican Americans. Political Behavior. 16(2):237-264.

Long, James and Clark C. Gibson. 2012. "Evaluating the Roles of Ethnicity and Performance in African Elections: Performance in African Elections: Evidence from an Exit Poll in Poll in Kenya." Political Research Quarterly 68 (4): 830-842.

Lublin, David. 2015. Electoral Systems, Ethnic Heterogeneity and Party System Fragmentation. British Journal of Political Science, pp1-17 DOI: http://dx.doi.org/10.1017/S0007123415000137

Martinez i Coma, F. 2016. Turnout determinants in democracies and in non-democracies. Electoral Studies, 41:50-59. 
Martinez i Coma, F. and Trinh, M. 2017. How electoral integrity affects voter turnout in democracies. Australian Journal of Political Science, 1-18. http://dx.doi.org/10.1080/10361146.2016.1238869

Massey, D., Denton, N. 1989. Hypersegregatioin in U.S. metropolitan areas: black and Hispanic segregation along five dimensions. Demography 26: 373-391.

Mauro, P. 1995. Corruption and Growth. Quarterly Journal of Economics 110:681-712.

McDonald M. P. and Popkin, S. 2001. The Myth of the Vanishing Voter. American Political Science Review 95(4): 963-974.

Milanovic, Branko L. 2014. All the Ginis, 1950-2012. Retrieved April $10^{\text {th }}$, 2017 from http://econ.worldbank.org/WBSITE/EXTERNAL/EXTDEC/EXTRESEARCH/0,,contentMDK:22301380 pagePK: 64214825 piPK:64214943 theSitePK:469382,00.html

Montalvo, J. G. and Reynal-Querol M. 2005a. Ethnic Diversity and Economic Development. Journal of Development Economics 76: 293-323.

Montalvo, J. G. and Reynal-Querol M. 2005b. Ethnic Polarization, Potential Conflict and Civil Wars. The American Economic Review 95(3): 796-816.

Morlan, R. L. 1984. Municipal vs. National Election Voter Turnout: Europe and the United States. Political Science Quarterly 99 (3):457-470.

Nohlen, D. 2005. Elections in the Americas: A Data Handbook. Vol. I: North America, Central America, and the Caribbean, Oxford: Oxford University Press

Nohlen, D. 2005 Elections in the Americas: A Data Handbook. Vol. II: South South America, Oxford: Oxford University Press.

Nohlen, D., Grotz, F. and Hartmann, C. 2001. Elections in Asia and the Pacific: A Data Handbook. Vol. I: Middle East, Central Asia, and South Asia, Oxford u. a.: Oxford University Press.

Nohlen, D., Grotz, F. and Hartmann, C. 2001. Elections in Asia and the Pacific: A Data Handbook. Vol. II: South East Asia, East Asia, and the South Pacific, Oxford u. a.: Oxford University Press.

Nohlen D., Krennerich, M. and Thibaut, B. 1999. Elections in Africa: A Data Handbook, Oxford: Oxford University Press.

Norris, P. and Mattes, R. 2003. Does Ethnicity Determine Support for the Governing Party? Voting and Democratic Citizenship in Africa. Ed. Michael Bratton. Lynne Reinner.

Oliver, E.J. 1999. The Effects of Metropolitan Economic Segregation on Local Civic Participation. American Journal of Political Science 43 (1): 186-212.

Persson, M., Sundell, A., Öhrvall, R. 2014. Does Election Day weather affect voter turnout? Evidence from Swedish elections. Electoral Studies (33): 335-342.

Posner, D. 2004. Measuring Ethnic Fractionalization in Africa. American Journal of Political Science 48, (4): 849863.

Putnam, R. D. 2007. E Pluribus Unum: Diversity and Community in the Twenty-first Century The 2006 Johan Skytte Prize Lecture Scandinavian Political Studies 30(2): 137-174.

Remmer, K. 2010. Political Scale and Electoral Turnout: Evidence From the Less Industrialized World. Comparative Political Studies, 43: 275-303.

Reynal-Querol, M. 2002. Ethnicity, Political Systems and Civil War, Journal of Conflict Resolution. Vol. 46(1): 2954

Robbins, J., Hunter, L. and Murray, G. 2013. Voters versus terrorists: Analyzing the effect of terrorist events on voter turnout. Journal of Peace Research 50(4): 495-508.

Roeder, P. 2003. Clash of Civilizations and the Escalation of Ethnopolitical Conflicts. Comparative Political Studies 36: 509-540.

Scarritt, J. R. and Mozaffar, S. 1999. The specification of ethnic cleavages and ethnopolitical groups for the analysis of democratic competition in contemporary Africa. Nationalism and Ethnic Politics 5(1):82-117. 
Schlichting, K., Tuckel, P, and Maisel, R. 1998. Racial segregation and voter turnout in urban America, American Politics Quarterly, 26(2): 218-236.

Solt, Frederick. 2008. Economic Inequality and Democratic Political Engagement. American Journal of Political Science, 52(1):48-60.

Solt, Frederick. 2010. Does Economic Inequality Depress Electoral Participation? Testing the Schattschneider Hypothesis. Political Behavior 32:285-301.

Steiner, N.D., 2010. Economic globalization and voter turnout in established democracies. Electoral Studies. 29(3): 444-59.

Stockemer, D., and Calca, P. 2012. Presidentialism and Voter Turnout in Legislative Elections. Parliamentary Affairs, 1-23.

Stockemer, D., LaMontagne, B., and Scruggs, L. 2011. Bribes and Ballots: The Impact of Corruption on Voter Turnout in Democracies. International Political Science Review 34(1): 74-90.

Stockemer, D. 2015. Turnout in developed and developing countries: Are the two turnout functions different or the same? Political Science, 67(1) 3-20.

Stockemer, D. 2016. What affects voter turnout? A review article/ meta-analysis of aggregate research, Government and Opposition doi:10.1017/gov.2016.30 1-25.

Teorell, J., Charron, N, Dahlberg, S., Holmberg S., Rothstein, B., Sundin, P. \& Svensson, R. 2013. The Quality of Government Dataset, version 30Apr13. University of Gothenburg: The Quality of Government Institute, URL: <http://www.qog.pol.gu.se>. Retrieved June 7, 2015.

Vanhanen, T. 1999. Domestic ethnic conflict and ethnic nepotism: a comparative analysis. Journal of Peace Research 36 (1): 55-73.

Weidmann, N. B. 2009. Geography as Motivation and Opportunity: Group Concentration and Ethnic Conflict. Journal of Conflict Resolution 53(4): 526-543. 
Tables and Figures

Table 1. Pairwise correlations of Different Measures of Ethnic Fractionalization

\begin{tabular}{|c|c|c|c|c|c|}
\hline Measure & $\begin{array}{l}\text { Atlas Narodov } \\
\text { Mira (1964) }\end{array}$ & $\begin{array}{l}\text { Alesina et al. } \\
(2003)\end{array}$ & Roeder (2003) & Fearon (2003) & $\begin{array}{l}\text { Montalvo and } \\
\text { Reynal-Querol } \\
(2005 a, 2005 b)\end{array}$ \\
\hline Alesina et al. (2003) & $0.71(515)$ & . & & & \\
\hline Roeder (2003) & $0.78(515)$ & $0.79(603)$ & . & & \\
\hline Fearon (2003) & $0.72(482)$ & $0.85(550)$ & $0.87(545)$ & . & \\
\hline $\begin{array}{l}\text { Montalvo and Reynal- } \\
\text { Querol (2005a, 2005b) }\end{array}$ & $0.77(501)$ & $0.83(573)$ & $0.85(491)$ & $0.81(613)$ & . \\
\hline
\end{tabular}

Note: Coefficients are Pearson's R, number of observations into parentheses

Table 2. Measures of ethnic diversity in our models

\begin{tabular}{lll}
\hline \hline Dimension & Measure & References \\
\hline Fractionalization (number of groups) & Ethnic Fragmentation & Alesina et al. (2003) \\
\hline Concentration of groups & $\begin{array}{l}\text { Territorial Concentration / } \\
\text { Group Dispersion }\end{array}$ & Weidmann (2009) \\
\hline Polarization (size of groups) & Ethnic Polarizazion Index & Reynal-Querol (2002) \\
\hline \hline
\end{tabular}


Table 3. Descriptive statistics for all variables in our models

\begin{tabular}{|c|c|c|c|c|c|c|}
\hline \multicolumn{2}{|l|}{ Variable } & $\overline{\mathbf{N}}$ & Mean & Std. Dev. & Min & Max \\
\hline \multicolumn{2}{|l|}{ Turnout } & 658 & 68.3 & 16.5 & 2.1 & 98.7 \\
\hline \multirow[t]{6}{*}{ Fractionalization } & Ethnic Fragmentation (Alesina et al. 2003) & 654 & .34 & .22 & 0 & .93 \\
\hline & Ethnic Fragmentation (Atlas Narodov Mira 1964) & 515 & .29 & .24 & .01 & .9 \\
\hline & Ethnic Fragmentation (Fearon 2003) & 550 & .37 & .23 & .003 & 1 \\
\hline & Ethnic Fragmentation (Roeder 2003) & 603 & .41 & .23 & .004 & .82 \\
\hline & $\begin{array}{l}\text { Ethnic Fragmentation (Montalvo and Reynal- } \\
\text { Querol 2005a, 2005b) }\end{array}$ & 573 & .36 & .25 & .01 & .93 \\
\hline & Religious Fragmentation (Alesina et al. 2003) & 654 & .42 & .23 & .004 & .82 \\
\hline \multirow[t]{2}{*}{ Concentration } & Territorial Concentration (country average) & 232 & .65 & .23 & .2 & 1 \\
\hline & Group Dispersion (country average) & 232 & 2.64 & 1.28 & 0 & 4.7 \\
\hline \multirow[t]{2}{*}{ Polarization } & Ethnic Polarization Index & 573 & .49 & .26 & .017 & .95 \\
\hline & Religious Polarization Index & 573 & .28 & .30 & .001 & .99 \\
\hline \multicolumn{2}{|l|}{ Population (log) } & 658 & 6.7 & 2.1 & 3 & 13.8 \\
\hline \multicolumn{2}{|c|}{ GDP per capita (log) } & 658 & 9 & 1 & 5.7 & 11.2 \\
\hline \multicolumn{2}{|l|}{ Urban rate (log) } & 658 & 4 & .5 & 1.9 & 4.5 \\
\hline \multicolumn{2}{|c|}{ Concurrent elections } & 658 & .15 & .35 & 0 & 1 \\
\hline \multicolumn{2}{|l|}{ Compulsory } & 658 & .26 & .44 & 0 & 1 \\
\hline \multicolumn{2}{|l|}{$P R$} & 658 & .49 & .5 & 0 & 1 \\
\hline \multicolumn{2}{|l|}{ Majoritarian } & 658 & .33 & .47 & 0 & 1 \\
\hline \multicolumn{2}{|c|}{ Effective number of parties (log) } & 658 & 1.28 & .43 & .2 & 2.6 \\
\hline \multicolumn{2}{|l|}{ Competitiveness } & 658 & 11.6 & 11.1 & 0 & 63.6 \\
\hline \multicolumn{2}{|c|}{ Number of elections } & 658 & 8.48 & 5.1 & 1 & 28 \\
\hline \multicolumn{2}{|l|}{1991} & 658 & .56 & .49 & 0 & 1 \\
\hline \multicolumn{2}{|l|}{ Type of election } & 706 & .93 & .25 & 0 & 1 \\
\hline \multicolumn{2}{|l|}{ Corruption } & 592 & .32 & .26 & 0 & .9 \\
\hline \multicolumn{2}{|l|}{ Gini } & 274 & 38.6 & 9.9 & 22.6 & 72.4 \\
\hline
\end{tabular}


Table 4. Determinants of aggregate turnout in elections worldwide (1960-2008)

\begin{tabular}{lcccccc}
\hline & M1 & M2 & M3 & M4 & M5 & M6 \\
\hline Constant & $64.01^{* * *}$ & $63.45^{* * *}$ & $71.85^{* * *}$ & $72.48^{* * *}$ & $64.36 * * *$ & $69.11^{* * *}$ \\
& $(0.975)$ & $(0.943)$ & $(2.544)$ & $(2.385)$ & $(1.070)$ & $(3.533)$ \\
Population $(\log )$ & $-2.720^{* * *}$ & $-2.244^{* * *}$ & 0.0686 & -0.566 & $-4.197 * * *$ & 2.107 \\
& $(0.580)$ & $(0.527)$ & $(1.425)$ & $(1.342)$ & $(0.563)$ & $(1.344)$ \\
GDP per capita $(\log )$ & $3.119 * * *$ & $1.836^{*}$ & $4.344 * *$ & $4.332^{* *}$ & $3.538^{* * *}$ & 2.002
\end{tabular}




\begin{tabular}{|c|c|c|c|c|c|c|}
\hline & $(0.944)$ & $(0.945)$ & $(1.968)$ & $(1.900)$ & $(0.972)$ & $(2.314)$ \\
\hline \multirow[t]{2}{*}{ Urban Rate (log) } & $2.468 * *$ & $1.862 *$ & $-3.230 *$ & -2.798 & 0.749 & $-3.420 *$ \\
\hline & $(1.052)$ & $(0.977)$ & $(1.888)$ & $(1.827)$ & $(1.046)$ & $(1.790)$ \\
\hline \multirow[t]{2}{*}{ Concurrent elections } & -1.525 & -0.579 & 3.059 & 2.942 & -0.378 & 4.914 \\
\hline & $(0.952)$ & $(0.902)$ & (3.267) & $(3.044)$ & $(0.869)$ & $(5.022)$ \\
\hline \multirow[t]{2}{*}{ Compulsory } & $2.365^{* * *}$ & $2.524 * * *$ & $4.548 * * *$ & $4.602 * * *$ & $3.568 * * *$ & $2.744 * *$ \\
\hline & $(0.717)$ & $(0.657)$ & $(0.704)$ & $(0.712)$ & $(0.680)$ & $(1.110)$ \\
\hline \multirow[t]{2}{*}{ PR } & $4.219 * * *$ & $3.351 * * *$ & $4.220 * * *$ & $3.719 * * *$ & $3.820 * * *$ & $7.183^{* * *}$ \\
\hline & $(0.928)$ & $(0.884)$ & $(1.182)$ & $(1.150)$ & $(0.914)$ & $(1.501)$ \\
\hline \multirow[t]{2}{*}{ Maj } & $3.867 * * *$ & $4.505^{* * *}$ & 0.389 & 0.481 & $4.452 * * *$ & 0.225 \\
\hline & $(1.109)$ & $(1.061)$ & $(1.549)$ & $(1.568)$ & $(1.117)$ & $(1.317)$ \\
\hline \multirow[t]{2}{*}{ Effective number of parties (log) } & -0.426 & 0.0863 & $-2.597 * * *$ & $-2.267 * * *$ & 0.288 & $-1.879 *$ \\
\hline & $(0.764)$ & $(0.737)$ & $(0.890)$ & $(0.878)$ & $(0.750)$ & $(1.011)$ \\
\hline \multirow[t]{2}{*}{ Competitiveness } & $-3.865 * * *$ & $-4.013^{* * *}$ & -0.375 & -0.0180 & $-4.015^{* * *}$ & $-4.096 *$ \\
\hline & $(1.387)$ & $(1.357)$ & $(1.915)$ & $(1.937)$ & $(1.492)$ & $(2.202)$ \\
\hline \multirow[t]{2}{*}{ Number of elections } & -0.843 & $-1.225^{* *}$ & 0.00670 & 0.643 & -0.991 & $-4.346 * * *$ \\
\hline & $(0.673)$ & $(0.613)$ & $(1.018)$ & $(0.868)$ & $(0.623)$ & $(0.999)$ \\
\hline \multirow[t]{2}{*}{1991} & -0.940 & -0.339 & $-2.664 * * *$ & $-3.079 * * *$ & -0.329 & 0.112 \\
\hline & $(0.663)$ & $(0.617)$ & $(0.888)$ & $(0.849)$ & $(0.659)$ & $(0.942)$ \\
\hline \multirow[t]{2}{*}{ Ethnic Fragmentation } & & $-6.678 * * *$ & & & & -1.123 \\
\hline & & $(0.738)$ & & & & $(3.012)$ \\
\hline \multirow[t]{2}{*}{ Religious Fragmentation } & & -0.539 & & & & \\
\hline & & $(0.830)$ & & & & \\
\hline \multirow[t]{2}{*}{ Territorial Concentration } & & & $-2.878 * * *$ & & & $-10.09 * * *$ \\
\hline & & & $(0.971)$ & & & $(2.147)$ \\
\hline \multirow[t]{2}{*}{ Group Dispersion } & & & & $2.386 * *$ & & \\
\hline & & & & $(1.015)$ & & \\
\hline \multirow[t]{2}{*}{ Ethnic Polarization Index } & & & & & $-4.752 * * *$ & -1.293 \\
\hline & & & & & $(0.626)$ & $(2.951)$ \\
\hline \multirow[t]{2}{*}{ Religious Polarization Index } & & & & & $-1.371 *$ & \\
\hline & & & & & $(0.820)$ & \\
\hline \multirow[t]{2}{*}{ Fragmentation*Polarization } & & & & & & -0.802 \\
\hline & & & & & & $(1.851)$ \\
\hline \multirow[t]{2}{*}{ Fragmentation*Concentration } & & & & & & $-7.106 * * *$ \\
\hline & & & & & & $(2.366)$ \\
\hline \multirow[t]{2}{*}{ Polarization*Concentration } & & & & & & 4.494 \\
\hline & & & & & & $(3.040)$ \\
\hline \multirow[t]{2}{*}{ Fragmentation*Concentration*Polarization } & & & & & & 0.0564 \\
\hline & & & & & & $(1.800)$ \\
\hline Observations & 658 & 654 & 232 & 232 & 573 & 173 \\
\hline R-squared & 0.314 & 0.372 & 0.501 & 0.500 & 0.442 & 0.675 \\
\hline Number of countries & 103 & 102 & 39 & 39 & 81 & 23 \\
\hline
\end{tabular}

Notes: Dependent variable is turnout in elections. Models are generalized least square models with panel corrected standard errors further corrected for panel-specific AR1 autocorrelation and heteroskedasticity. Coefficients are standardized regression coefficients, standard errors in parentheses. ${ }^{*} p<.05 ;{ }^{*} p<.01$; $* * * p<.001$ 


\section{Notes}

'Putnam's arguments (2007) are along the same lines.

ii In one of the robustness checks in section 5.2, we also include presidential elections in the analysis.

iii With the exception of nations that held elections on the eve of their independence from colonial rule (such as Nigeria in 1959).

iv Elections where the franchise was limited to a very small (and ethnically defined) segment of the population, e.g. South Africa (before 1994), are not included.

${ }^{\vee}$ A democracy is 'a regime in which governmental offices are filled as a consequence of contested elections. This definition has two main parts: 'offices' and 'contestation.' For a regime to be democratic, both the chief executive office and the legislative body must be filled by elections. Contestation occurs when there exists an opposition that has some chance of winning office as a consequence of elections' (2010: 69).

vi See Appendix A for the complete list of countries and elections included in our analyses. Table A1 lists all the parliamentary elections, whereas Table A2 lists all the presidential elections.

vii This definition of turnout matches IDEA's definition of 'vote/VAP', which is also the most common in the academic literature (Geys, 2006). http://www.idea.int/vt/glossary.cfm\#Voter Turnout

viii This difference is worth mentioning because there may be divergences with the official statistics reported in many countries. Registration processes may also exclude a substantial portion of the population, such as the prison population in the US (Macdonald and Popkin, 2001).

ix For the elections included in the analysis, the correlation is $R=.96(p<.001)$.

${ }^{x}$ For example, IDEA has different numbers on the registry of their voters for the parliamentary and the presidential elections in Kenya in 1997. While for the former they have 9,030,092 voters, for the latter, they give $5,095,850$ voters. We have checked with other sources (i.e. African Election Database), and the registry was closer to 9 million.

${ }^{x i}$ We are also aware of the presence of 'constructivist' measures-those referring to 'the act of actually using one or more identities embedded in this structure to guide behavior' (Chandra 2009: 309). For this paper, however, we rely on the structural measures as we are neither offering mechanisms nor explaining how the identities are 'activated' by politicians. Obviously, a work focusing on such measures and turnout will be of utmost relevance. Another issue to consider that the reviewers highlighted is the time invariance character of the measures upon which we rely. Certainly, the data available for the three dimensions are constant. In that regard, such a variable behaves as an electoral system in many countries that does not change over time. However, the use of time invariant measures is justified, even if global time series were available. In our view, changes in the ethnic composition of countries are only significantly affected in cases of important external shocks, as changes are normally very slow over time. The work from Posner for Africa (2004) provides an example of what we mean. Posner detailed the evolution of the politically relevant ethnic groups (PREG). In his appendix, he provided calculations for 42 African countries in the 1960s, 70s, 80s and 90s. Out of the possible 126 changes from one decade to the next, he only registered 6 changes (less than 5 per cent of the cases). Finally, and as an additional robustness check (available in the online documentation), we have re-run the analysis in a 'static' mode in which the unit of observation is the country and not the election. For each country, we have averaged the turnout rate as well as the independent variables since 1980 for the 102 democracies included in the original analysis. As can be seen, ethnic fragmentation is significant and negative, as shown in $\mathrm{M} 2$ in Table 4. Furthermore, we have repeated the analysis but with the averaged turnout rate (and the independent variables) since 1990 and then since 2000. The results are in Table B9 in the online appendix. As can be seen, ethnic diversity, jointly with compulsory vote and PR systems, keep the significance and the expected sign.

xii More detail on the computation of such an index can be found in Weidmann (2009).

xiii Weidman's individualised measure correlates at almost 0.8 .

xiv Montalvo and Reynal-Querol (2005a and 2005b) also considered religious polarisation, which ranges from 0 to 1 and takes very low values in Turkey but very high values in Kenya. Religious polarisation correlates 0.267 with political polarisation and is included in our empirical analyses as a control.

${ }^{\mathrm{xv}}$ We are constrained by the measures on which we rely which conditions the varying number of cases included in the analysis. While Alesina et al. (2003) included almost every country in the world (190), the coverage from Reynal-Querol and Montalvo (2002) was lower (138). When considering the values on group 
concentration from Weidmann (2009), the coverage decreases to 72 states in Europe, Asia and North Africa. Also, many of such countries are not democracies, substantially affecting the number of observations included. xvi We have also run the model including the Polity definition of democracy and previous turnout. The results hold and are available in the online documentation.

xvii Stockemer et al. (2011) and Martinez i Coma (2016) relied on the ICRG Indicator of Quality of Government as a measure of corruption. V-Dem's indicator, however, maximises the number of observations. Both measures, however, correlate over 0.78 , and the results with such a variable (not reported) are very similar.

xviii In a further robustness check (not reported), we included both corruption and inequality simultaneously as controls. The results did not change. 